\title{
Phytochemical and In vitro Antidiabetic Activity of Psidium Guajava Leaves
}

\author{
Ramasamy Manikandan ${ }^{1}$, Arumugam Vijaya Anand², Sampath Kumar ${ }^{3}$ and Pushpa ${ }^{4}$ \\ 'Department of BioChemistry, M.I.E.T Arts and Science College, Trichirappalli-620 007, Tamil Nadu, INDIA. \\ ${ }^{2}$ Department of Human Genetics and Molecular Biology, Bharathiar University, Coimbatore-641 046, Tamil Nadu, INDIA. \\ ${ }^{3}$ Department of Chemistry and Biosciences, SASTRA University, Kumbakonam-612 001, Tamil Nadu, INDIA. \\ ${ }^{4}$ Department of Microbiology, Cauvery College for Women, Tiruchirappalli-620 018, Tamil Nadu, INDIA.
}

\begin{abstract}
Objective: The present investigation includes the preliminary screening of phytochemicals and evaluation of an in vitro antidiabetic activity of Psidium guajava leaves extracts. Materials and Methods: Plant material was subjected to the extract preparation by soxhlet apparatus by using various solvents such as aqueous, ethanol, chloroform, petroleum ether and hexane. The various kinds of phytochemicals were detected and then in vitro antidiabetic activity of $P$. guajava leaves were detected by using alpha amylase and alpha glucosidase enzyme in an in vitro model. Results: The study reveals the presence of phytochemicals such as carbohydrate, tannin, flavonoids, phenols etc., Among the various extracts the aqueous and ethanolic extracts which contains the large number of phytoconstituents. The $P$. guajava leaves has been successfully inhibited both the enzymes in an in vitro model. The aqueous extracts of $P$ guajava leaves inhibited the alpha amylase and alpha glucosidase enzymes as $72.1 \%$ and $74.8 \%$
\end{abstract}

respectively. The ethanolic extract of $P$. guajava leaves inhibited the alpha amylase and alpha glucosidase enzymes as $97.5 \%$ and $91.8 \%$ respectively. Conclusion: From the results obtained in the current studies, the $P$. guajava leaves have a prominent antidiabetic property in an in vitro model and further studies can be carried out in an in vivo model and the isolation of activie compound from $P$. guajava leaves extract is needed.

Key words: Alpha amylase, Alpha glucosidase, P. guajava, Phytochemical.

Corresponding author: Mr. Ramasamy Manikandan, Assistant Professor, Department of BioChemistry, M.I.E.T Arts and Science College, Tiruchirappalli620 007, Tamilnadu, India.

Phone No: +91 9894898103 :

Email: mani_r_trichy@yahoo.co.in

DOI : 10.5530/pj.2016.4.13

\section{INTRODUCTION}

Diabetes mellitus is a leading metabolic disorder in worldwide and India is the capital for diabetes. Diabetes is a condition in which the body does not produce enough insulin or properly respond to insulin. Insulin is a hormone which is produced in $\beta$ cells of pancrease. It stimulates the body cells to absorb glucose from blood. Diabetes mellitus is one of the most common endocrine metabolic disorder which causes the various micro vascular and macro vascular complications. ${ }^{1}$ Microvascular complications are most common in type 1 diabetes mellitus which includes retinopathy, neuropathy and nephropathy and Macrovascular complications includes heart attack, stroke and peripheral vascular diseases etc. Nearly $2.8 \%$ of the world's population affected by diabetes and it is expected to increases upto $5.4 \%$ in the year of $2025 .{ }^{2}$ Various kinds of antidiabetic therapies such as sulphonylureas, biguanides, glinides etc, are available, but it causes various adverse effects. So, the researchers are investigate and try to find more effective and safer hypoglycemic agent without causing any side effects. ${ }^{3}$ Herbal medicines are derived from plant extract are being used to treat a wide variety of clinical diseases. ${ }^{4}$ Many of the pharmaceutical compounds which are present as a secondary metabolites in plants. Thus objective of the present study is to investigate the phytochemical and find the in vitro antidiabetic activity of various extracts of Psidium guajava leaves.

\section{MATERIALS AND METHODS}

\section{Plant material and extraction}

The fresh leaves of P. guajava were collected locally and authenticated by the department of Botany, St. Joseph College, Trichy. The shade dried $P$. guajava leaves were powdered mechanically and stored in an air tight container. The extraction was carried out by hot percolation method using Soxhlet apparatus. The various solvents such as water, ethanol, chloroform, petroleum ether and hexane were used. About $100 \mathrm{gm}$ of powder was extracted with $600 \mathrm{ml}$ of the various solvents. The extract was concentrated to dryness under controlled temperature $40-50^{\circ} \mathrm{C}$. The extract was preserved in refrigerator till further use.

\section{Phytochemical Screening}

For preliminary phytochemical analysis the freshly prepared various crude extracts of leaves of P. guajava were subjected to find the presence or absence of phytoconstituents such as reducing sugar, tannins, flavonoids, steroids and alkaloids by using standard phytochemical procedures. ${ }^{5}$

\section{In vitro methods employed in antidiabetic studies Inhibition of alpha-amylase enzyme}

A starch solution $(0.1 \% \mathrm{w} / \mathrm{v})$ was obtained by stirring $0.1 \mathrm{~g}$ of potato starch in $100 \mathrm{ml}$ of $16 \mathrm{mM}$ of sodium acetate buffer. The enzyme solution was prepared by mixing $27.5 \mathrm{mg}$ of alpha-amylase in $100 \mathrm{ml}$ of distilled water. The colorimetric reagent is prepared by mixing sodium potassium tartarate solution and 3, 5-di nitro salicylic acid solution 96 $\mathrm{mM}$. The starch solution is added to the both control and plants extract tubes and left to react with alpha-amylase solution under alkaline conditions at $25^{\circ} \mathrm{C}$. The reaction was measured over 3 minutes. The generation of maltose was quantified by the reduction of 3, 5-dinitro salicylic acid to 3-amino-5-nitro salicylic acid. This reaction is detectable at $540 \mathrm{~nm} .^{6}$

\section{Inhibition of alpha-glucosidase enzyme}

The inhibitory activity was determined by incubating a solution of starch substrate ( $2 \% \mathrm{w} / \mathrm{v}$ maltose or sucrose) $1 \mathrm{ml}$ with $0.2 \mathrm{M}$ Tris buffer of $\mathrm{pH}$ 8.0 and various concentrations of plant extract for $5 \mathrm{~min}$ at $37^{\circ} \mathrm{C}$. The reaction was initiated by adding $1 \mathrm{ml}$ of alpha-glucosidase enzyme $(1 \mathrm{U} / \mathrm{ml})$ to it followed by incubation for $40 \mathrm{~min}$ at $35^{\circ} \mathrm{C}$. Then the reaction was terminated by the addition of $2 \mathrm{ml}$ of $6 \mathrm{~N} \mathrm{HCl}$. Then the intensity of the colour was measured at $540 \mathrm{~nm}^{7}$ 
Table1: Phytochemical analysis of $P$. guajava leaves of various extracts

\begin{tabular}{|c|c|c|c|c|c|c|}
\hline Phytochemical Constituents & Name of the Test & Aqueous & Ethanol & Chloroform & Petroleum Ether & Hexane \\
\hline Alkaloids & Mayer's test & - & + & - & + & - \\
\hline Carbohydrate & Molish Test & + & + & + & + & + \\
\hline Tannin & Lead acetate test & + & + & + & - & - \\
\hline Terpenoids & Noller test & - & + & + & - & - \\
\hline Steroidal glycosides & Salkowaski test & + & + & - & - & - \\
\hline Quinones & $\mathrm{H}_{2} \mathrm{SO}_{4}$ test & + & + & - & + & - \\
\hline Anthraquinone & Borntrager's test & - & + & - & + & - \\
\hline Saponin glycosides & $\mathrm{H}_{2} \mathrm{SO}_{4}$ test & - & + & - & - & - \\
\hline Flavonoids & Schioda's test & + & + & + & - & - \\
\hline Total protein & Biuret test & + & + & - & - & - \\
\hline Fixed Oil & Spot test & - & + & - & - & - \\
\hline Phenols & $\mathrm{FeCl}_{3}$ test & - & + & - & - & - \\
\hline Coumarin & $\mathrm{NaCl}$ test & - & + & - & - & - \\
\hline
\end{tabular}

+ = Present; $-=$ Absent.

Table 2: In vitro Antidiabetic activity of aqueous and ethanolic extracts of P. guajava leaves by alpha amylase method

\begin{tabular}{ccc}
$\begin{array}{c}\text { Concentration of } \\
\text { Sample }\end{array}$ & $\begin{array}{c}\text { \% of inhibition of } \\
\text { aqueous extract }\end{array}$ & $\begin{array}{c}\text { \% of inhibition of } \\
\text { ethanolic extract }\end{array}$ \\
\hline 0.2 & 16.2 & 29.6 \\
0.4 & 31.5 & 51.2 \\
0.6 & 49.7 & 65.6 \\
0.8 & 61.3 & 89.2 \\
1.0 & 72.1 & 97.5 \\
$\mathrm{IC}_{50}$ & 0.62 & 0.49 \\
\hline
\end{tabular}

\section{Calculation of $50 \%$ Inhibitory Concentration $\left(\mathrm{IC}_{50}\right)$}

The concentration of the plant extracts required to scavenge $50 \%$ of the radicals $\left(\mathrm{IC}_{50}\right)$ was calculated by using the percentage scavenging activities at five different concentrations of the extract. Percentage inhibition (I\%) was calculated by $\mathrm{I} \%=($ Ac-As $) / A c \mathrm{X} 100,{ }^{8}$ where Ac is the absorbance of the control and As is the absorbance of the sample.

\section{RESULTS}

Table 1 shows the results of various phytoconstituents present in the different extracts of $P$. guajava leaves. Phytochemical screening of aqueous, ethanol, chloroform, petroleum ether and hexane extracts exposed the presence of alkaloids, carbohydrate, tannins, terpenoids, flavonoids, phenols, total protein etc., by using various methods. Phytochemical screening showed that the maximum phytoconstituents were present in the aqueous and ethanolic extracts.

Table 2 shows the results of in vitro Antidiabetic activity of aqueous and ethanolic extracts of $P$. guajava leaves by the use of alpha amylase enzyme. There was a significant increase of percentage of inhibitory activity was noticed in a concentration dependent manner. At a concentration of $0.2 \mathrm{ml}$ of the aqueous extract and ethanolic extract have the inhibitory activity of $16.2 \%$ and $29.6 \%$ respectively. The maximum concentration of $1.0 \mathrm{ml}$ of the aqueous extract have $72.1 \%$ of inhibitory effect and ethanolic extract possessed $97.5 \%$ of inhibitory activity against the alpha amylase enzyme.

Table 3 shows the results of in vitro antidiabetic activity of the leaves extract of P. guajava in alpha glucosidase method. These extracts which
Table 3: In vitro Antidiabetic activity of aqueous and ethanolic extracts of $P$. guajava leaves by alpha glucosidase method

\begin{tabular}{ccc}
\hline $\begin{array}{c}\text { Concentration of } \\
\text { Sample }\end{array}$ & $\begin{array}{c}\text { \% of inhibition of } \\
\text { aqueous extract }\end{array}$ & $\begin{array}{c}\text { \% of inhibition of } \\
\text { ethanolic extract }\end{array}$ \\
\hline 0.2 & 26.3 & 33.6 \\
0.4 & 34.2 & 55.2 \\
0.6 & 51.9 & 70.4 \\
0.8 & 63.7 & 82.7 \\
1.0 & 74.8 & 91.8 \\
$\mathrm{IC}_{50}$ & 0.58 & 0.49 \\
\hline
\end{tabular}

revealed the significant inhibitory action of alpha glucosidase enzyme in a dose dependent manner. In aqueous extract, the inhibitory percentage varied from $26.3 \%-74.8 \%$, and the inhibitoty effect of ethanolic extract varied from $33.6 \%-91.8 \%$.

\section{DISCUSSION}

The carbohydrate metabolic disorder may causes various health problems such as diabetes, oral diseases, obesity etc., in worldwide. Diabetes mellitus is mainly due to the lack of insulin secretion or action. The treatment of type-II diabetes includes the stimulation of insulin secretion, inhibition of breakdown of polysaccharides and disaccharides etc. ${ }^{9}$

Alpha amylase and alpha glucosidase are the carbohydrate metabolizing enzymes. These enzymes are mainly involved in the degradation of oligosaccharides and disaccharides into monosaccharides. ${ }^{10-12}$ The inhibition of these enzymes increases the carbohydrate digestion time and reduces the glucose absorption. ${ }^{13}$ Various inhibitors such as acarbose, viglibose etc are available to inhibit alpha amylase and alpha glucosidase enzymes but it causes various side effects such as diarrhoea, bloating etc. ${ }^{14}$ Various plant extracts were reported that the in vitro antidiabetic activity of plants due to the inhibitory effect of alpha amylase and alpha glucosidase enzymes.

The methanolic extract of $P$. guajava leaves have an in vitro antidiabetic activity in a dose dependent manner by the inhibitory activity of alpha amylase and alpha glucosidase enzymes, ${ }^{15}$ aqueous extract of Syzygium Cumini seeds and P. guajava leaves have inhibition activity against the alpha amylase and alpha glucosidase enzymes in a concentration dependent manner. ${ }^{16}$ 
A plant derived compounds such as alkaloids, terpenoids, polysaccharides, glycosides etc., have an antidiabetic activity against hyperglycemia. In the present study, the phytochemical analysis proves that various phytoconstituents are present in various extracts of $P$. guajava leaves. Particularly the aqueous and ethanolic extracts of P.guajava leaves which contains enormous number of constituents such as carbohydrates, tannins, alkaloids etc.

The present study to evaluate and to compare the in vitro antidiabetic activity of aqueous and ethanolic extracts of $P$. guajava leaves in alpha amylase and alpha glucosidase method. Both the extracts have an antidiabetic activity, when compared to aqueous extract, the ethanolic extracts of $P$. guajava leaves have a high inhibitory activity on alpha amylase and alpha glucosidase enzymes. Further studies are needed to find that which compound is actively involved in the antidiabetic activity of the P. guajava leaves.

\section{CONCLUSION}

The present study clearly proved that the extract of $P$. guajava leaves have an antidiabetic activity in an in vitro model. So further in vivo studies and compound isolation studies are needed.

\section{ACKNOWLEDGEMENT}

The authors are grateful to The Chairman, M.I.E.T. Institutions, for his guidance and encouragement.

\section{CONFLICT OF INTEREST}

The authors have no conflict of interest.

\section{ABBREVIATION USED}

P. guajava: Psidium guajva.

\section{REFERENCES}

1. Patel DK, Kumar R, Prasad SK, Sairam K, Hemalatha S. Antidiabetic and in vitro antioxidant potential of Hypanthus enneaspermus (Linn) F. Muell in streptozotocin-induced diabetic rats. Asian Pac J Trop Biomed. 2011;1(4):316-22.

2. Patel DK, Prasad SK, Kumar R, Hemalatha S. An overview on antidiabetic medicinal plants having insulin mimetic property. Asian Pac J Trop Biomed. 2012;2(4):320-30

3. Saxena A, Vikram NK. Role of selected Indian plants in management of type 2 diabetes: a review. J Altern Complement Med. 2004;10(2):369-78.

4. Karyano S, Kikuzaki H, Fukutsuka N, Mitani T, Nakatani N. Antioxidant activity of prune (Prunus domestica L.,) constituents and a new synergist. J Agric Food Chem. 2002;50(13):3708-12

5. Evans WC, Evans T. Pharmacognosy. $5^{\text {th }}$ Edn, Cambridge University Press, London; 2003. 336-93

6. Malik CP, Singh MB. Plant Enzymology and Histoenzymology. Kalyani Publishers, New Delhi; 1980. p. 278.

7. Krisnaveni S, Theymoli B, Sadasivam S. Food Chem. 1984;15:229.

8. Shai LJ, Masoko P, Mokgotho MP, Magano SR, Mogale MA, Boaduo N, et al. South African J. Bio. 2010;76:465-70.

9. Funke I, Melzing MF Traditionally used plants in diabetes therapy - phytotherapeutics as inhibitors of a-amylase activity. Rev Bras Farmacogn. 2006;16(1):1-5.

10. Laar FA, Lucassen PLBJ, Akkermans RP, Lisdonk EH, Rutten GEHM, Weel C. Alpha-glucosidase inhibitors for type 2 diabetes mellitus (Cochrane Review). The Cochrane Library; 2008

11. Inzucchi SE. Oral antihyperglycemic therapy for type 2 diabetes. JAMA. 2002; 287:360-72

12. Lebowitz HE. Alpha-glucosidase inhibitors as agents in the treatment of diabetes. Diabetes Rev. 1998;6(2):132-45

13. Cheng AYY, Fantus IG. Oral antihyperglycemic therapy for type 2 diabetes Mellitus. Can. Med. Assoc. J. 2005;17(2):213-26.

14. Chakrabarti R, Rajagopalan R. Diabetes and insulin resistance associated disorders: Disease and the therapy. Current Science. 2002;83(12):1533-8.

15. Manikandan R, Vijaya Anand A, Durai Muthumani G. Phytochemical and in vitro anti-diabetic activity of ethanolic extract of $P$. guajava leaves. Int J Curr Microbiol App Sci. 2013;2(2):15-9

16. Karthic K, Kirthiram KS, Sadasivam S, Thayumanavan B. Identification of amylase inhibitors from Syzygium cumini Linn seeds. Indian J. Exp. Biol. 2008;46(9):677-80.

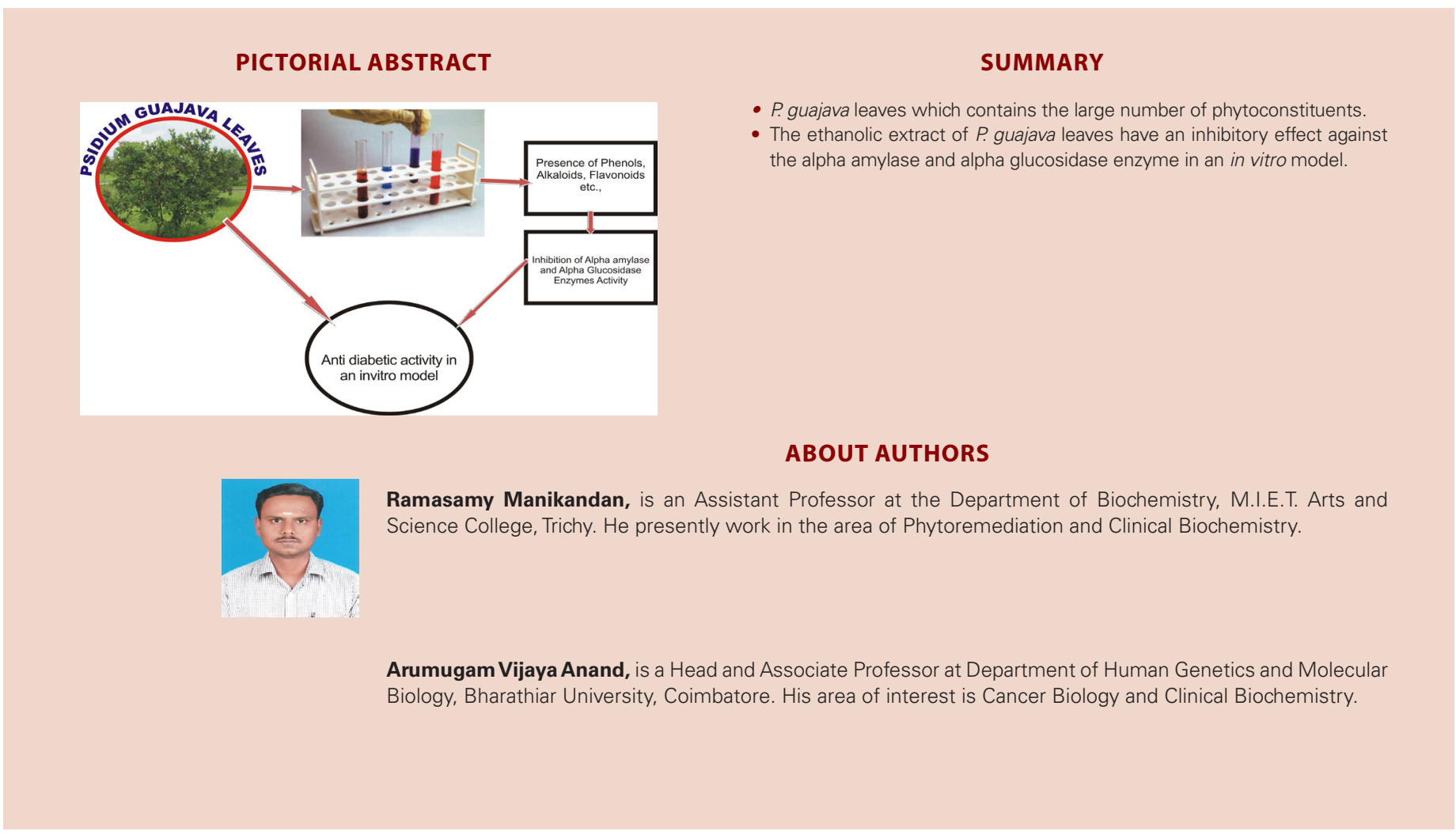

